\title{
Exploratory Study on Internalization of Character Values through Educational Profession Course
}

\author{
Mesterjon $^{1}$, Suwarni $^{2}$, Diah Selviani ${ }^{3}$ \\ ${ }_{1,2,3}$ Universitas Dehasen Bengkulu, Indonesia \\ mesterup@yahoo.co.id,suwarni@unived.ac.id,diah.selviani@unived.ac.id
}

\begin{abstract}
This study was based on the findings during teaching and learning process at FKIP Universitas Dehasen Bengkulu (the Faculty of Educational Science and Teacher Training of Dehasen University of Bengkulu). There was a phenomenon of declining of good character value and morality. This is because of the misused of advancing technology by students that brings negative impact on the students' character and morality. This phenomenon was especially found among new students of FKIP (Faculty of Educational Science and Teacher Training) on their early stage of study. At the meeting of Educational Profession (Profesi Pendidikan) course, we did early observation by making contract with the new student. . They generally still brought their local character and moralor their old behavior. This could be seen, for example, they talked to their lecturers and seniors impolitely or often used their local language. Everyone's patience was needed in dealing withthis phenomenon. As the lectures progressed, especially Educational Profession course, we tried to internalize character values toward the students. This had positive impact for them. Today, they are found to be more polite, for example, they greet their lecturers and seniors when they meet them. This study dealt with character values such as: religious, discipline, honest, hard work, responsible, love peace, appreciate achievements, and friendly or communicative. This Exploratory study which was done to internalize character value of the students, has positive impact, this can be seen fromthepositive progress of students' character. Students who already have good character will keep learning to have better personality. This wil affect their future job, especially if they become teachers.
\end{abstract}

\author{
Keywords \\ exploratory study, \\ character value; \\ educational profession
}

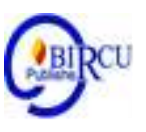

\section{Introduction}

There is a phenomenon of declining character and morality nowadays. This is due to the misused of advancing technology by the youth of the nationthat brings negative impact to the nobel character and moral of the students. This was especially found among new students of FKIP (Faculty of Education Science and Teacher Training) on their early stage of study. This was observed at the first meeting during the courseof Educational Profession (ProfesiPendidikan) when the contract was made.

Etymologically, when traced from the origin of the word, the word character comes from the Latin "khhar", "kharassein", "kharax", which means to make sharp and make deep. (Abdul Majid: 2011). In terminology, character is interpreted as a way of thinking and behaving that is unique to each individual for live and work together, both within the scope of the family, community, nation and state. Character can be considered as the values of human behavior related to God Almighty, oneself, and fellow humans. Environment and nationality manifested in thoughts, words and actions based on religious, 
legal, etiquette, culture, customs and aesthetic norms. Character is behavior that appears in everyday life both in attitude and in action (Muchlas Samani dan Hariyanto: 2011).

Personality and character development patterns must be carried out systematically and continuously by involving aspects of knowledge, feelings, and actions. Character education can also be instilled, both in the family, community, and school. The most ideal foundation in character education is the values of faith and piety (Siregar et al, 2020). According to Sembiring et al (2019) Character is the attitude and way of thinking, behaving and interacting as a characteristic of an individual in life, acting and working together, both within the scope of the family, community and nation.

Abdullah et al (2019) stated that character education is a learning to be virtuous and good morals. Nobility and morality are based on the concepts of the state and values in society to be instilled in students. This was held as a form of mutual concern to overcome moral depravity in Indonesia which was eroded by the presence of increasingly rapid technology. Character is influenced by heredity (heredity). The behavior of a child is often not far from the behavior of the parents. Character is also influenced by the environment. Children who are in a good environment, tend to have good character, and vice versa. Character refers to a series of attitudes, behaviors, motivation, and skills. Character is the overall natural disposition and disposition that has been controlled in a stable manner that defines an individual in his overall psychic behavior which makes him typical in the way of thinking and acting (Zubaidi : 2011).

At the next meeting there were many students breaking the rule. In the contract, class will be started at 7, unfortunately more than $80 \%$ students came late. Muslim students were only $20 \%$ performed fajr prayer. This brought great impact toward their attitude and behavior. The description of each character value designed by Pusat Kurikulum Badan Penelitian dan Pengembangan Kementrian Pendidikan Nasional can be seen as follows:

Table 1. List of Character Values based on the design of Kemendiknas (Ministry of National Education)

\begin{tabular}{|c|l|l|}
\hline No & Character Value & \multicolumn{1}{c|}{ Description } \\
\hline 1 & Religious & $\begin{array}{l}\text { Attitude and behavior of obeying religion teaching, tolerance } \\
\text { of other religion's application, and living harmoniously with } \\
\text { other religion's believers }\end{array}$ \\
\hline 2 & Honest & $\begin{array}{l}\text { Attitude and action of tolerating diffrence of religion, race, } \\
\text { ethnic, opinion, attitude, and action of others }\end{array}$ \\
\hline 3 & Tolerant & $\begin{array}{l}\text { Action that shows attitude of obeying various kind of rules and } \\
\text { regulations }\end{array}$ \\
\hline 4 & Discipline & $\begin{array}{l}\text { Hard work Actions that demonstrate orderly and obedient } \\
\text { behavior on various rules and regulations } \\
\text { Thinking and doing something to produce ways or new result } \\
\text { from something already owned }\end{array}$ \\
\hline 5 & Hardwork & $\begin{array}{l}\text { Attitude and behavior of not depending on other people in } \\
\text { accomplishing tasks }\end{array}$ \\
\hline 6 & Creative & $\begin{array}{l}\text { Way of thinking, having attitude, and acting of believingthat } \\
\text { everyone has the same right and obligation }\end{array}$ \\
\hline 8 & Democratic & $\begin{array}{l}\text { Attitude and action which always try to deepen and enlarge } \\
\text { something learnt,seen and heard }\end{array}$ \\
\hline 9 & Curious & $\begin{array}{l}\text { Way of thinking,acting and understanding which puts the nation } \\
\text { and state's interest above one interwst and group's interest }\end{array}$ \\
\hline 10 & Nationalism & \multicolumn{2}{|l}{} \\
\hline
\end{tabular}




\begin{tabular}{|c|l|l|}
\hline 11 & Patriotic & $\begin{array}{l}\text { Way of thinking,acting and understanding which put nation } \\
\text { and state' interestover one's interest and group' s interest }\end{array}$ \\
\hline 12 & Appreciation & $\begin{array}{l}\text { Attitude and action which drive one to produce something } \\
\text { useful for society, and recognize and also appreciate others' } \\
\text { achievement }\end{array}$ \\
\hline 13 & $\begin{array}{l}\text { Friendly/communi } \\
\text { cative }\end{array}$ & $\begin{array}{l}\text { Attitude and action which motivate one to produce something } \\
\text { useful for society, and recognize and also appreciate others' } \\
\text { achievement }\end{array}$ \\
\hline 14 & Peace-loving & $\begin{array}{l}\text { Attitude and action which motivate one to produce something } \\
\text { useful for society }\end{array}$ \\
\hline
\end{tabular}

Fuad Hasan, an education expert in Indonesia, explained that the purpose of education is to transfer cultural values and social norms (transmission of culture values and social norms). Meanwhile, Mardiatmadja stated that character education is the spirit of education in humanizing humans. So that in simple terms, the goals of character education can be formulated to change humans for the better, in knowledge, attitudes and skills. (Abdul Majid: 2011).

From the list of the table above, the writer concluded to internalize character value that should be possessed by students of FKIP such as religious, discipline, honest, hard work, and responsible. The internalization of these character valueswas done through exploratory study that can make students' moral and character to be better in the future since they are going to be educators in the future.

\section{Research Methods}

This type of research is qualitative research, because based on the formulation of the problem, this research is a qualitative research using descriptive methods. Qualitative data are very interesting. Qualitative data are the source of a broad and well-founded description and contain descriptions of processes occurring in the local environment). "Qualitative data are sexy. They are a source of well-grounded, richdescriptions and explanations of processes in dentifiable local contexts" (Matthew B Miles and Michael Huberman, 1994: 1).

The subject of this study were students of the second semester of FKIP Universitas Dehasen academic year 2019/2020. The writers have considerated this because the subject fitthe objective of the study. According to Sugiyono (2011:224) data collection technique is the most strategic step in a study/research, because the objective of a study is to collect data. "Data Reduction refers to the process of selecting, focusing, simplifying, abstracting and transforming the data that appear in written up field notes or transcription" (Matthew B Miles and Michael Huberman, 1994:1).

Data collection in this study was done through:

\section{Observation}

This activity is done to find out the condition of the subject of the study. The first thing carried out before doing study/research is observation. Observation is meant to be systematic observation and recording toward the symptoms seen on the object of study (Margono, 2009:158)

2. Giving UTS (Mid-Term Test) and UAS (Final Test)

Testswere given by distributing test sheet containing mid-term test and final test items. The subject were given opportunity to accomplish the task and then interviewed 
with interview questions based on the subjects' answers (which was guided by interview guidance).

3. Interview

Esterberg (in Sugiyono, 2011: 231) defines interview as "a meeting of two persons to exchange information and idea through questions and responses, resulting in communication and joint construction of meaning about a particular topic".

4. Triangulation

Mathison (Sugiyono, 2011: 241) states that " the value of triangulation lies in providing evidence-weather convergent,inconsistent, or contradictory". Thus, with this technique, the collected data will be more consistent, complete, and exact. Triangulation can build on the strengths of each type of data collection while minimizing the weakness in any single approach (Patton in Sugiyono, 2011:241).

\section{Results and Discussion}

\subsection{Religious}

Religious has very close relation with students' religious value. Their ethic and moral are observed from how they feel God's power during learning process. The internalization of religious character value was done by saying gratefulness to God and praying before starting lesson and after finishing lesson and also by saying the greeting. Besides, they also prayed in order to be focused and understand the lesson.

Table 2. Application of Character Value of Religious Table

\begin{tabular}{|c|l|l|}
\hline No & \multicolumn{1}{|c|}{ Attitude of Character Value of Religious } & \multicolumn{1}{c|}{$\%$ of Students } \\
\hline 1 & Praying before starting lesson & $100 \%$ \\
\hline 2 & Praying after finishing lesson & $95 \%$ \\
\hline 3 & Greeting & $90 \%$ \\
\hline
\end{tabular}

From the above table, it can be seen that after internalizing students' religious character value consisting three indicators, it shows that $100 \%$ students have already prayed before starting learning process, $95 \%$ have prayed after finishing learning process, and $90 \%$ say the greeting.

\subsection{Discipline}

Internalization of discipline character value to students is something obligatory for students because we are as Indonesian citizens must apply discipline especially relate to time. After effort of internalizing character value of discipline, there is significant change. All students already present 5 minutes before starting lesson. They all wear proper clothes as demanded as educator.There is no more student wearing t-shirt and tight jeans. The percentage of Internalization of DisciplineCcharacter Value can be seen bellow:

Table 3. Table of internalization of Character Value of Discipline

\begin{tabular}{|l|l|l|}
\hline No & Attitude of character value of Discipline & $\%$ of students \\
\hline 1 & Punctual & $100 \%$ \\
\hline 2 & Proper clothes & $95 \%$ \\
\hline
\end{tabular}


The inculcation of student disciplinary character values in the professional education course is that $100 \%$ of students have come 5 minutes before learning begins, as well as the costumes or clothes used $95 \%$ have followed the rules in accordance with the FKIP vision and mission to produce character educators.

\subsection{Honest}

Internalization of honest character value to students is in order that students can be trustful individuals; it is believed that one lie triggers another. Students' honest character value is observed from their words and actions. During learning process especially midterm and final test they worked hard without cheating. This can be seen from their answer sheets that shows different answers. When they did wrong such as skipping class or coming late, they tried to explain it honestly, it can be observed from their answer, they did not make up answers. Result of internalization of character value of honesty can be seen bellow:

Table 4. Internalization of Character Value of Honesty Table

\begin{tabular}{|l|l|l|}
\hline No & Character Value of Honesty & $\%$ of students \\
\hline 1 & UTS (Mid term test) & $90 \%$ \\
\hline 2 & UAS (Final test) & $95 \%$ \\
\hline
\end{tabular}

From the table it can be seen that during mid-term test and final test, 90\% students hasdone the tests by themselves without cheating during mid-term test, and $95 \%$ during final test. Internalization of honesty is very important in each learning process. Judging from the picture above, it can be seen that at the time of carrying out the UTS and UAS $90 \%$ of the UTS activities they had done it themselves without cheating, likewise at the time of carrying out the UAS there had been an increase of $95 \%$ they did what they could. The cultivation of honest character values is very important in every lesson.

\subsection{Hard Work}

Internalization of hardworking character value is very important. This character value which is a must for students is significant capital for their future. Students who work hard from the early stage of college life have more strength to overcome challenges in the future. Hardworking in term of Educational Profession courseis doing well all assignments given by lecturers, submit them in the given time and doing them with perseverance. Doing assignments whole heartedly brings positive impact for students, they will become perseverant educators in the future. The observation result can be seen bellow:

Table 5. Internalization of Character value of Hardworking Table

\begin{tabular}{|l|l|l|}
\hline No & Character value of hardworking & $\%$ of students \\
\hline 1 & Doing assignment & $90 \%$ \\
\hline 2 & Perseverance & $90 \%$ \\
\hline
\end{tabular}

The work character values from the table above during the learning of the professional education course. Based on the results of observations made, $90 \%$ of all are good at doing tasks and being serious in dealing with learning situations. Judging from the results of the task they have done that have been maximally good. 


\subsection{Responsible}

Internalization of responsibility character valuewas observed from students' attitude and behavior in doing assignments of Educational Profession course. Students should have responsibility because it brings positive impact for themselves as future educators. Students' responsibility character value can be seen from how they do assignment such as group assignment, and presentation of group's paper which is done maximally. Form of responsibility character value can be seen bellow:

Table 6. Internalization of Character Value of Responsibility Table

\begin{tabular}{|l|l|l|}
\hline No & Character value of responsibility & $\%$ of students \\
\hline 1 & Group's assignment & $90 \%$ \\
\hline 2 & Group's presentation & $95 \%$ \\
\hline
\end{tabular}

From the table it can be seen that the internalization of this character value is already satisfied. In doing group's assigment 90\% students have done their assigment well and 95\% students have been responsible together to present the assigment well and cooperatively. The internalization of responsibility is in order that the students become responsible persons not only on campus but also in their family life and in their society in the future.

\subsection{Love Peace}

Peace-loving characters are attitudes, words, and actions that cause other people to feel happy and secure in their presence. Respect for others by using polite language, a good attitude is one form of peace-loving character shown by students Form of responsibility character value can be seen bellow:

Table 7. Internalization of Character Value of Love Peace Table

\begin{tabular}{|l|l|l|}
\hline No & Character value of Love Peace & $\%$ of students \\
\hline 1 & Respect each other & $95 \%$ \\
\hline 2 & Supporting Each Other & $95 \%$ \\
\hline
\end{tabular}

The character of love and peace is shown by students by supporting and respecting each other by using polite language during the learning process. The observation results show that as many as $95 \%$ of students who respect each other as well as students who support them. Students always use polite language in learning so that no other students are distracted. In addition, the character of peace-loving can be seen from the attitude of students who do not show anger because they do not understand learning. One more attitude shown by students in applying the peace-loving character, namely they never underestimate other students because they do not understand well learning both verbally and gestures.

\subsection{Appreciate Achievements}

Character respects achievement, namely attitudes and actions that encourage him to produce something useful for society and recognize and respect the success of others. Winning or losing a match is something to be grateful for and accept. The actions that students show are a form of character appreciating achievement, shown by the students by shaking the hand of the winning team, cheering along, then acknowledging, and respecting the success of other groups. There were also congratulations spoken, indicating that the students appreciated the achievements of their opponents. This attitude is also highly 
emphasized in every sport activity which is better known as sportsmanship. Form of character Appreciate Achievements value can be seen bellow:

Table 8. Internalization of Character Value of Appreciate Achievements Table

\begin{tabular}{|l|l|l|}
\hline No & Character value of Love Peace & $\%$ of students \\
\hline 1 & Congratulate & $85 \%$ \\
\hline 2 & Be happy with your friends' achievements & $80 \%$ \\
\hline
\end{tabular}

The character of appreciating achievement can be shown by students by acknowledging student victories and shaking hands or saying the success of friends who get achievements. There were $85 \%$ of students who congratulated their other friends, while $80 \%$ were also very happy with the success of their friends' achievements, seen from their verbal movements and responses. The character that must be accustomed to responding to classmates' pretensions is because it will make the student's character a person who will respect the abilities of other students to be more creative and enthusiastic in learning.

\subsection{Friendly or Communicative}

Friendly or communicative character is an act that shows a sense of pleasure to talk, socialize, and cooperate with others. Being calm in learning in dealing with the assignments given by the lecturer is shown by a communicative character if there are parts that do not understand. Learning that requires a focus in learning so that it makes students better understand the material given. Form of character Friendly or Communicative value can be seen bellow:

Table 9. Internalization of Character Value of Friendly or Communicative Table

\begin{tabular}{|l|l|l|}
\hline No & Character value of Love Peace & $\%$ of students \\
\hline 1 & Friendly & $90 \%$ \\
\hline 2 & Communicative & $90 \%$ \\
\hline
\end{tabular}

In learning, a friendly or communicative character is needed by both students and lecturers so that teaching and learning activities run well. Judging from the table above that a friendly and communicative attitude reaches $90 \%$, this shows that learning runs optimally and learning objectives are achieved.

\section{Conclusion}

Teaching and learning activities at the FKIP Dehasen University Bengkulu.There is a phenomenon of declining of character of students in the teaching and learning process at FKIP Universitas Dehasen Bengkulu. This study deals with internalization of character value of religious, discipline, honesty, hardworking and responsibility. Regarding the formation of children's character, parents have a very big responsibility. Parents play an important role in the education of their children from the time they are in the womb, after birth, to adulthood. . This study dealt with character values such as: religious, discipline, honest, hard work, responsible, love peace, appreciate achievements, and friendly or communicative. This Exploratory study which was done to internalize character value of the students, has positive impact, this can be seen from the positive progress of students' character. Students who already have good character will keep learning to have better personality. This will affect their future job, especially if they become teachers. Exploration study which was carried out in internalization of character value brought 
positive effect for rhe students due to the progress of students' character values have a good impact on students due to progress in terms of student character for the better. Students who have had good character will try to learn to be better persons in the future.

\section{References}

Abdul Majid dan Dian Andayani. 2011. Pendidikan Karakter Perspektif Islam. Bandung: PT Remaja Rosdakarya.

Abdullah, A.R., et al. (2019). The Value of Social Care Character Education Through Merindu Baginda Nabi. Budapest International Research and Critics Institute-Journal (BIRCI-Journal). P. 493-501.

Jamal Ma'mur Asmani. 2011. Buku Panduan Pendidikan Karakter Di Sekolah. Yogyakarta: Diva Press.

Margono, S. 2009. Metodologi PenelitianPendidikan.Jakarta: Rineka Cipta

Matthew B Miles and A. Michael Huberman. 1994. Qualitative Data Analysis.London: Sage Publication

Selviani, D. (2017). Studi Eksplorasi tentang Representasi Matematis Siswa SMP untuk Bahasan SPLDV (Sistem Persamaan Linear Dua Variabel) Ditinjau Berdasarkan Extended Level Triad++. EDU-MAT: Jurnal Pendidikan Matematika, 5(1), 53-62.

Sembiring, A.S., et al. (2019). Character Formation Based on North Sumatra Local Wisdom Through Orchestral Learning in Music Education Study Program, Universitas Negeri Medan. Budapest International Research and Critics InstituteJournal (BIRCI-Journal). 315-325.

Siregar, S.F., Mardianto and Ahkas, A.W. (2020). Extracurricular Implementation of Islamic Education in Character Building Students in MTs EX PGA UNIVA Medan. Budapest International Research and Critics in Linguistics and Education (BirLE) Journal. P. 965-973.

Putry Raihan. 2018. Nilai Pendidikan Karakter Anak Di Sekolah Perspektif Kemendiknas. Jurnal Gender Quality, Internasional Journal Of Child And Gender Studies. Vol 4, No.1, Maret 2018. ISSN 2461-1468/E: ISSN:2548-1954

Sugiyono. 2011. Metode Penelitian Pendidikan Pendekatan Kuantitatif, Kualitatif danR \& D. Bandung: Alfabeta.

Zubaedi. 2011. Desain Pendidikan Karakter Konsepsi dan Aplikasinya dalam Lembaga Pendidikan. Jakarta: Kencana.

Muchlas Samani dan Hariyanto.2011. Konsep dan Model Pendidikan Karakter. Bandung: PT Remaja Rosda Karya. 